\title{
COMMUNITY OF PRACTITIONERS : SOLUSI ALTERNATIF BERBAGI PENGETAHUAN ANTAR PUSTAKAWAN
}

\author{
Supriyadi ${ }^{*}$ ) \\ ${ }^{1}$ Program Doktor Interdisciplanary Islamic Studies Konsentrasi Ilmu Perpustakaan dan Informasi Islam \\ *) Korespondensi : Supriyadi.jondhy@gmail.com
}

\begin{abstract}
[Title: Community of Practioner: an Alternative Solution for Knowledge Sharing among Librarian] This paper presents the importance of community of practitioners in knowledge sharing among librarians. It is expected to serve as a solution for problems associated with the work of librarians, related to either technical, conceptual, or planning issues. This paper employed library research method or approach. The data were collected by analyzing and/or exploring some journals, books, both printed and electronic documents, and other sources and/or information that relate to the research. There are three main characteristics distinguishing a community of practitioners from other communities, namely Domain, Community and Members those that should come from practitioners who had the same profession. This type of community is only bound by trust among members although in its development, the establishment of this community begins to enter the system or the management of a company as a forum for internal knowledge sharing. Sharing knowledge related to job becomes a special characteristic in a community of practitioners, and its output can produce new knowledge that we call innovation in solving a problem or a job including library issues. In the context of library, the implementation of community of practitioners is by grouping librarians based on the area of the job or position, for example a group of librarians from the circulation area, a group of librarians from the procurement area, a group of librarians from the shelving area, and so on. All of these practitioners meet to share knowledge with their fellow practitioners in a community which we referred to as community of practitioners.
\end{abstract}

Keywords: Community of Practitioners, Knowledge Sharing, Librarians

\begin{abstract}
Abstrak
Tujuan Tulisan ini menyajikan tentang pentingnya komunitas praktisi dalam berbagi ilmu pengetahuan (knowledge sharing) antara sesama pustakawan, dengan harapan menjadi problem solving dari setiap persoalan yang berhubungan dengan pekerjaan pustakawan, baik berkaitan dengan hal-hal yang bersifat teknis, konsep atau pun perencanaan. Metodologi atau Pendekatan - yang digunakan dalam tulisan ini menggunakan metode atau pendekatan kepustakaan (library research), sedangkan pengumpulan data dilakukan dengan menelaah dan/atau mengekplorasi beberapa Jurnal, buku, dan dokumen-dokumen (baik yang berbentuk cetak maupun elektronik) serta sumber-sumber data dan atau informasi lainnya yang dianggap relevan dengan kajian.Temuan dalam kajian ini adalah Pada komunitas praktisi ada tiga karakteristik yang menjadi pembeda utama dari komunitas-komunitas lainnya yaitu, ada Domain, Community dan anggota harus berasal dari para praktisi yang mempunyai kesamaan profesi, komunitas ini hanya diikat oleh trust antara sesama anggota walaupun pada perkembangannya pembentukan komunitas ini mulai masuk sistem atau manajemen suatu perusahaan sebagai wadah knowledge sharing internal. Berbagi ilmu pengetahuan terkait pekerjaan menjadi ciri khas dari komunitas praktisi dan output nya dapat memproduksi ilmu-ilmu baru yang kita sebut sebagai inovasi dalam menyelesaikan suatu persoalan atau pekerjaan tak terkecuali di perpustakaan. Diperpustakaan komunitas praktisi dilakukan dengan cara mengelompokkan para pustakawan berdasarkan bidang perkerjaan atau jabatan, antara sirkulasi dengan bidang sirkulasi, pengadaan antar sesama pengadaan, bagian shelving dengan sesama bagian shelving dan begitu seterusnya, dan sетиа para praktisi ini bertemu untuk berbagi pengetahuan dengan sesama praktisinya dalam suatu komunitas yang kita sebut sebagai kumunitas praktisi.
\end{abstract}

Kata Kunci : Komunitas Praktisi, Berbagi Pengetahuan, dan Pustakawan 


\section{Pendahuluan}

Perkembangan ilmu pengetahuan yang kian melaju, menjadikan semua para praktisi khususnya praktisi perpustakaan berlomba-lomba untuk mencapai titik pengetahuan ideal, yaitu pengetahuan yang mampu menjadi solusi alternative dalam setiap persoalan yang dihapinya. Pustakawan sebagai abdi informasi harus menjadi insan pembelajar agar dapat dan mampu memenangkan persaingan dalam memberikan pelayanan informasi kepada masyarakatnya. Menjadi pemenang dalam persiangan di era global yang sangat konpetitif seperti saat ini tentu sangat sulit dan tidak dapat dilakukan secara indvidu oleh seorang pustakawan. Untuk mengatasi kesulitan tersebut perlu dilakukan knowledge sharing atau berbagi pengetahuan antar sesama pustakawan. Disinilah peran knowledge sharing dikalangan pustakawan menjadi amat penting untuk meningkatkan kemampuannya dengan harapan dapat menghasilkan inovasi terbaru untuk pengembangan perpustakaan kedepan.

Salah satu tools berbagi yang cukup potensial adalah membangun dan mengembangkan komunitas keahlian atau Community of practitioner $(\mathrm{CoP})$. CoP merupakan suatu komunitas yang dibangun untuk memfasilitasi pertukaran pengetahuan secara tacit ke tact (Tim Knowledge Management PT. PLN Persero, 2009: iii). Dengan melalui CoP ini, maka setiap pustakawan yang mempunyai pengetahuan dan minat pada bidang yang sama, dapat berkumpul, berdiskusi, belajar, saling berbagi pengetahuan dan pengalaman untuk memecahkan masalah atau melakukan inovasi untuk mencapai kinerja di perpustakaan yang lebih baik. CoP pada dasarnya merupakan wadah yang tepat untuk terbentuknya best practitioner di lingkungan perpustakaan dan juga dapat menumbuhkan kepercayaan antar anggota, sehingga kondisi ini membuat aktifitas pertukaran pengetahuan dapat terfasilitasi dengan baik.

Community of practitioner diperlukan karena kegiatan transfer knowledge akan lebih mudah dilakukan pada suatu kelompok dengan lingkup kerja yang sama sehingga saling memahami karakter satu sama lain dan memiliki kepercayaan lebih dengan individu penyampai knowledge. Hal ini terjadi karena budaya trust merupakan budaya yang sangat berpengaruh pada berjalannya proses transfer knowledge.

\section{Landasan Teori}

\section{Definisi Community of Practitioner}

Community of Practitioner (CoP) adalah kelompok orang yang berbagi suatu perhatian atau semangat untuk sesuatu yang mereka kerjakan dan belajar bagaimana caranya melakukan itu lebih baik ketika mereka saling berinteraksi secara teratur (Trayner, 2015:1). Sedangkan definisi lainnya CoP diartikan sebagai sekumpulan orang yang mempunyai kepentingan dan minat yang sama atas suatu masalah dan berusaha bersama untuk memperoleh pemecahannya (Tim Knowledge Management PT. PLN Persero, 2009: 2-3).

Istilah CoP pertama kali dipakai pada tahun 1991 oleh Jean Lave dan Etienne Wenger. Mereka menggunakan istilah ini dalam hubungannya dengan pembelajaran yang diposisikan sebagai bagian dari usaha untuk "rethink learning" di Institute for Research on Learning. Pada 1998, Etienne Wenger 
mengembangkan konsep tersebut dan mengaplikasikannya dalam konteks lain, termasuk seting organisasi.

Baru-baru ini, CoP dikaitkan dengan knowledge management sebagai cara mengembangkan modal sosial, memelihara pengetahuan baru, merangsang inovasi, atau berbagi pengetahuan tasit yang ada di dalam suatu organisasi. Sekarang CoP diterima sebagai bagian dari pengembangan organisasi

\section{Metode / Pendekatan Kajian}

Metode yang digunakan dalam kajian ini menggunakan metode atau pendekatan kepustakaan (library research), Studi pustaka atau kepustakaan dapat diartikan sebagai serangkaian kegiatan yang berkenaan dengan metode pengumpulan data pustaka, membaca dan mencatat serta mengolah bahan penelitian ( Zed, 2003:3). Dalam penelitian studi pustaka setidaknya ada empat ciri utama yang penulis perlu perhatikan diantaranya : Pertama, bahwa penulis atau peneliti berhadapan langsung dengan teks (nash) atau data angka, bukan dengan pengetahuan langsung dari lapangan. Kedua, data pustaka bersifat "siap pakai" artinya peniliti tidak terjung langsung kelapangan karena peneliti berhadapan langsung dengan sumber data yang ada di perpustakaan. Ketiga, bahwa data pustaka umumnya adalah sumber sekunder, dalam arti bahwa peneliti memperoleh bahan atau data dari tangan kedua dan bukan data orisinil dari data pertama di lapangan. Keempat, bahwa kondisi data pustaka tidak dibatasi oleh runga dan waktu (Zed, 2003:4-5). Berdasarkan dengan hal tersebut diatas, maka pengumpulan data dalam penelitian dilakukan dengan menelaah dan/atau mengekplorasi beberapa Jurnal, buku, dan dokumen-dokumen (baik yang berbentuk cetak maupun elektronik) serta sumber-sumber data dan atau informasi lainnya yang dianggap relevan dengan penelitian atau kajian.

\section{Pembahasan}

\subsection{Perkembangan Community of Practitioner}

Community of Practitioner mulai terbentuk sejak masa Yunani klasik, yaitu bermula dari "korporasi" pekerja logam, pembuat pot, tukang batu, dan para pekerja jenis keterampilan lainnya yang masing-masing mempunyai tujuan sosial (anggotanya menyembah kepada dewa yang sama dan merayakan hari libur bersama-sama) dan fungsi bisnis (anggotanya berlatih keahlian dan keterampilan guna mengembangkan kreativitas dan inovasi) dapat dianggap sebagai contoh komunitas praktis. Selanjutnya pada masa pertengahan, Gilda yang memainkan peran yang sama seperti para penggiat seni diseluruh daratan Eropa juga dapat dianggap sebagai komunitas praktis. (Haedar Akib dan Frans Gana, 2008:100)

Dewasa ini, komunitas praktis memiliki satu perbedaan penting dengan komunitas-komunitas lainnya, yakni disamping terdiri dari gabungan orang-orang yang kebanyakan bekerja dalam perusahannya sendiri, maka komunitas praktis saat ini sering eksis pada organisasi besar. Salah satu contoh, CoP yang terkenal adalah yang dibentuk oleh para teknisi perbaikan mesin foto kopi di perusahaan Xerox. Melalui jaringan dan berbagi pengalaman, terutama masalah yang mereka temui dan 
solusi yang mereka pikirkan, kelompok inti teknisi ini membuktikan peningkatan efisiensi dan efektivitas usaha untuk mendiagnosis dan memperbaiki mesin foto kopi pelanggan Xerox. Dampaknya pada kepuasan pelanggan dan nilai bisnis terhadap Xerox tidak ternilai. Namun, pertemuan informal dan berbagi keahlian ini adalah sukarela, bukan program perusahaan (Zulaiha, 2008 :2).

Community of Practitioner dianggap unik karena memiliki banyak keuntungan tak terduga yang tidak dapat ditemukan dalam proses Manajemen Pengetahuan lainnya. Ada beberapa alasan mengapa Community of Practitioner dianggap unik menurut (Veronica, 2012 : 85-89), diantaranya adalah:

1. Membangun pengetahuan menjadi "Best Practice".

Karena anggota Komunitas Praktek adalah para praktisi, dengan kata lain orang-orang yang telah memasuki angkatan kerja, sehingga mereka akan menjadi kontributor yang akan membawa banyak ide-ide dan gagasan baru untuk membangun pengetahuan untuk menjadi praktek terbaik.

2. Meningkatkan kualitas pengetahuan dan pelaksanaannya di masa depan. Proses diskusi di Komunitas Praktek tidak hanya dapat meningkatkan kualitas pengetahuan untuk menjadi lebih baik, tetapi juga memastikan proses implementasinya untuk menjalankannya dengan sempurna.

3. Pengetahuan yang ditargetkan pada permasalahan yang nyata

Untuk alasan yang sama, karena praktisi ini, fokus dari Komunitas Praktek adalah penggunaan pengetahuan dalam pemecahan masalah yang dapat digunakan secara langsung dalam pekerjaan organisasi

4. Memungkinkan munculnya inovasi baru

Komunitas Praktek tidak terbatas pada pengetahuan yang diberikan, bukan tidak mungkin jika pada saat pengembangan pengetahuan tersebut akan muncul pengetahuan baru yang dapat dikembangkan oleh para anggotanya.

5. Mendorong minat anggotanya menjadi aktif dalam proses belajar mengajar Dalam Komunitas Praktek akan muncul banyak kontributor pengetahuan, dan ini akan mempengaruhi orang lain untuk melakukan hal yang sama, sehingga akan membangun budaya belajar dan mengajar.

6. Efisien

Komunitas Praktek tidak akan memerlukan banyak biaya dan tenaga, karena ketika Komunitas Praktek ini berjalan, maka akan ada semangat anggotanya untuk terus mendukung komunitas ini.

7. Belajar Mandiri

Berbeda dengan metode lain dari penyebaran pengetahuan, dalam Komunitas Praktek setiap anggota dapat meminta anggota lain (tidak guru) yang sudah mengerti pengetahuan. Jadi ketersediaan guru tidak begitu diperlukan lagi. 
8. Membangun Hubungan

Komunitas Praktek dapat membangun hubungan yang lebih baik antara para anggotanya, hal ini karena persamaan kepentingan dan pengetahuan mereka untuk membahas kegiatan mereka selalu didiskusikan bersama.

9. Pengembangan Karakter

Selain mengembangkan pengetahuan yang dibahas, Komunitas Praktek juga akan mengembangkan kepribadian anggotanya (Character Building) melalui proses pembelajaran, sehingga organisasi juga akan mendapatkan keuntungan.

10. Meninjau kembali bakat setiap anggota

Komunitas Praktek akan membuka bakat / pengetahuan / praktek diadakan secara rahasia pada anggota organisasi. Hal ini lebih jauh akan memperkaya pengetahuan organisasi. Selain pengungkapan bakat / pengetahuan / praktek yang dimiliki oleh anggota organisasi, organisasi memiliki keuntungan karena dapat menggunakan sumber daya dari keanggotaan yang ada

11. Membangun budaya positif dalam organisasi

Bila dilihat dari sisi organisasi, Komunitas Praktek juga dapat membangun budaya budayapositif dari para anggota diwajibkan untuk membangun organisasi yang kuat dan produktif.

\subsection{Karakteristik Community of Practitioner}

Community of Practitioner berbeda dengan bentuk organisasi lain dalam beberapa hal (Wenger dan Snyder : 2000). Secara sederhana, Community of Practitioner berbeda dengan team. Team diciptakan oleh para manajer untuk menyelesaikan proyek tertentu. Manajer menyeleksi anggota team dengan dasar kemampuan yang dimiliki untuk disumbangkan bagi pencapaian tujuan team dan kelompoknya bubar setelah proyek berakhir. Sementara itu, Community of Practitioner bersifat informal-mengorganisir dirinya sendiri, yang berarti pula menetapkan agenda kerja dan mengembangkan sendiri kepemimpinannya. Disamping itu, ciri keanggotaan Community of Practitioner dipilih dengan sendirinya oleh orang yang bergabung didalamnya. Dengan kata lain, orang-orang dalam $C o P$ cenderung tahu kapan dan dalam hal apa perlu bersama-sama anggotanya. Anggota CoP juga tahu sekiranya memliki sesuatu untuk diberikan kepada kelompok dan juga tahu apakah ada kemungkinan memperoleh sesuatu dari kelompoknya.

Untuk lebih jelasnya mari kita lihat sekilas perbandingan antara Community of Practitioner dengan komunitas lainnya sebagaimana tabel 1 berikut: 
Tabel 1.Perbandingan komunitas praktisi dengan komunitas lainnya, (Wenger dan Snyder :2000)

\begin{tabular}{|c|c|c|c|c|}
\hline & Tujuan & Yang dimiliki & $\begin{array}{l}\text { Apa yang berlaku } \\
\text { bersama }\end{array}$ & $\begin{array}{l}\text { Berjalan berapa } \\
\text { lama }\end{array}$ \\
\hline $\begin{array}{l}\text { Komunitas } \\
\text { Praktis }\end{array}$ & $\begin{array}{l}\text { Untuk mengembangkan } \\
\text { kemampuan anggota, } \\
\text { untuk membangun dan } \\
\text { bertukar pengetahuan }\end{array}$ & $\begin{array}{l}\text { Anggota yang } \\
\text { memilih sendiri }\end{array}$ & $\begin{array}{l}\text { Semangat, } \\
\text { kometmen dan } \\
\text { mengidentifikasi } \\
\text { keahlian kelompok }\end{array}$ & $\begin{array}{l}\text { Selama ada minat } \\
\text { dalam } \\
\text { mempertahankan } \\
\text { kelompok }\end{array}$ \\
\hline $\begin{array}{l}\text { Kelompok } \\
\text { Kerja Formal }\end{array}$ & $\begin{array}{l}\text { Untuk Mengantar } \\
\text { produk dan pelayanan }\end{array}$ & $\begin{array}{l}\text { Setiap orang } \\
\text { melaporkan } \\
\text { kepada manajer } \\
\text { kelompok }\end{array}$ & $\begin{array}{l}\text { Kebutuhan kerja } \\
\text { dan tujuan umum }\end{array}$ & $\begin{array}{l}\text { Sampai reorganisasi } \\
\text { selanjutnya }\end{array}$ \\
\hline Tim Proyek & $\begin{array}{l}\text { Untuk menyelesaikan } \\
\text { tugas khusus }\end{array}$ & $\begin{array}{l}\text { Karyawan } \\
\text { ditugaskan oleh } \\
\text { manajer senior }\end{array}$ & $\begin{array}{l}\text { Pencapaian dan } \\
\text { tujuan proyek }\end{array}$ & $\begin{array}{l}\text { Sampai proyek } \\
\text { selesai }\end{array}$ \\
\hline $\begin{array}{l}\text { Jaringan } \\
\text { Informal }\end{array}$ & $\begin{array}{l}\text { Untuk mengumpulkan } \\
\text { dan menyampaikan } \\
\text { informasi bisnis }\end{array}$ & $\begin{array}{l}\text { Teman-teman } \\
\text { dan rekan bisnis }\end{array}$ & $\begin{array}{l}\text { Saling } \\
\text { membutuhkan }\end{array}$ & $\begin{array}{l}\text { Selama orang } \\
\text { mempunyai alasan } \\
\text { untuk terhubung }\end{array}$ \\
\hline
\end{tabular}

Menurut (Wenger, 2006: 1-2) Untuk membedakan antara Community of Practitioner dengan komunitas lainnya paling tidak ada tiga karakteristik yang penting untuk diperhatikan yaitu:

\section{1) Domain}

CoP bukan kumpulan teman-teman atau jaringan koneksi di antara orang-orang, tetapi mempunyai identitas yang telah ditetapkan dengan domain minat tertentu. Keanggotaannya menyiratkan komitmen kepada domain, dan itu yang membedakannya dengan kelompok lainnya.

\section{2) The Community}

Untuk memenuhi minat dalam domain mereka, para anggota terlibat dalam aktivitas dan diskusi, saling menolong, dan berbagi informasi.

\section{3) The Practitioner}

Para anggota Community of Practitioner adalah praktisi. Mereka berbagi praktek atau pengalaman, cerita, tools, metode, dan teknik mengatasi permasalahan. Banyak yang dilakukan orang-orang dalam organisasi terjadi dalam konteks CoP. Tempat di mana best practitioner dan inovasi pertama muncul dan solusi untuk berbagi masalah pertama kali diidentifikasi.

\subsection{Metode Merancang dan Membangun sebuah Community of Practitioner}

Dalam merancang dan membangun Community of Practitioner, dapat menggunakan model 5D yaitu : Discovery, Dreaming, Design, Document dan Disseminate (Veronica, 2012:7): 


\section{1) Discovery / Penemuan}

Eksplorasi hubungan dengan organisasi melalui narasi individu, tahap ini adalah interaksi awal antara anggota dengan menceritakan tentang diri mereka sendiri. Ada beberapa hal yang diperlukan untuk dipertimbangkan seperti latar belakang anggota, pengetahuan (knowledge / praktek) yang mereka miliki, tujuan mereka dalam organisasi dan harapan mereka dalam organisasi, dll.

\section{2) Dreaming / Bermimpi}

Tahap ini merupakan tahap menggabungkan hal-hal yang telah ditemukan pada temuan ke dalam visi atau tujuan yang sama mendukung pengembangan manajemen pengetahuan organisasi dengan menciptakan visi dan tujuan yang diharapkan dapat menciptakan sebuah komunitas yang kuat karena mereka memiliki tujuan yang sama.

3) Design/Perancangan

Setelah memperoleh tujuan yang ingin dicapai, pada tahap ini, desain dan pengembangan proses operasional apa yang ingin dicapai mulai dilakukan. Pada tahap ini, akan ada diskusi pengetahuan, hubungan pengetahuan dengan pekerjaan masing-masing anggota, peran masing-masing anggota dalam organisasi, teknologi dan infrastruktur yang diperlukan untuk memastikan pengetahuan yang dapat dibuat, dibagi dan didokumentasikan.

4) Dokumen

Pada tahap ini, masyarakat diijinkan untuk belajar dan berkembang. Tergantung pada tahap awal, anggota organisasi tersebut akan mulai berdiskusi baik langsung atau tidak langsung (misalnya melalui berbagai media online), atau mengadakan pertemuan singkat untuk membahas pengetahuan. Fase ini akan mulai membuka pandangan orang lain yang sebelumnya kurang tertarik. Kemudian, seiring dengan perkembangan pengetahuan, orang lain yang tidak tertarik akan mulai tertarik untuk berpartisipasi dalam komunitas praktis. Pekerjaan manajerial pada tahap ini adalah melakukan pemantauan dan mendokumentasikan dari semua hasil belajar mereka. Melaksanakan dokumentasi sedetail mungkin dan melakukan apa pun yang bisa didokumentasikan, misalnya dalam bentuk dokumen, file, gambar peristiwa, poster, dan mencatat hasil dari semua kegiatan.

\section{5) Disseminasi / Menyebarkan}

Tahap diseminasi / sosialisasi memiliki dua fase utama, pertama, secara rutin melakukan atau menyebarkan semua dokumentasi yang diperlukan semua anggota organisasi. Kedua adalah menciptakan pertemuan tatap muka secara teratur untuk mendiskusikan apa yang telah anggota organisasi pelajari dan berbagi dengan anggota lain. Pada tahap ini akan ada hubungan sosial baru antara anggota dan hal itu akan membangun masa depan organisasi. 


\subsection{Knowledge Sharing antar pustakawan melalui Community of Practitioner}

Knowledge Sharing pada Community of Practitioner di perpustakaan menjadi solusi alternative dalam mengembangkan dan atau berbagi pengetahuan para pustakawan. Karena komponen utama dalam organisasi perpustakaan adalah individu atau orang, maka organisasi pembelajar baru akan tercapai dengan adanya proses pembelajaran oleh individu-individu yang ada di perpustakaan secara kolektif. Perpustakaan sebagai lembaga yang mengelola informasi yang aktivitasnya lebih dominan dalam hal teknis, knowledge sharing pada Community of Practitioners dapat membantu meningkatkan pengetahuan yang dimiliki pustakawan dan juga dapat membantu men-shering-kan suatu inovasi yang ingin di buat atau dikembangkan oleh pustakawan dalam memajukan perpustakaannya.

Dalam kontek perpustakaan knowledge sharing pada community of practitioner dapat dilakukan dengan cara mengelompokkan para pustakawan sesuai dengan bidangnya masing-masing. Misalnya bagian pelayanan atau sirkulasi dapat membuat kelompok sesama bagian pelanyanannya atau sirkulasi, pengolahan sesama bidang pengolahan, pengadaan sesama bagian pengadaannya dan begitu juga dengan bidang-bidang yang lainnya, dan selanjutnya dapat menggunakan kerangka konsep 5D diatas, yaitu Discovery, Dreaming, Design, Document dan Disseminate.

Knowledge sharing pada Community of Practitioner di perpustakaan tidak hanya dilakukan untuk internal satu lembaga saja tapi bisa juga direncanakan antar sesama perpustakaan yang mempunyai kesamaan wilayah pekerjaan atau domain tergantung kesepakatan anggota komunitas. Dalam community of practitioner para praktisi perpustakaan dapat menggali pengetahuan sedalam-dalamnya yang bersingungan langsung dengan pekerjaannya dan atau berbagi pengetahuan yang dimilikinya kepada sesama anggota komunitas. Apabila komunitas praktek ini dapat berjalan dengan awet maka sinergistas antar sesama praktisi akan terbangun dan inovasi-inovasi terbaru akan selalu muncul dari hasil berbagi pengetahuan tersebut.

Adapun tujuan Pembentukan Cummunity of Practitioner di perpustakaan diantaranya : a) Sebagai wadah berbagi pengetahuan dan kolaborasi dalam rangka membantu pekerjaan sehari-hari, b) Untuk menggali potensi pengetahuan yang ada di masing-masing pustakawan demi membangun pengetahuan para pustakawan dimasing-masing bidang, c) Sebagai wadah untuk mengembangkan continuous improvement dan membangun disiplin perencanaan dan pendokumentasian yang sesuai, dan d) Sebagai wadah utama untuk menumbuh kembangkan inovasi-inovasi yang berasal dari pustakawan.

\subsection{Penerapan Community of Practitioner di perpustakaan}

Pertumbuhan ilmu pengetahuan dan media informasi semakin berkembang cepat. Tidak sedikit informasi muncul dengan kemasan-kemasan media informasi baru yang menciptakan kemudahan akses bagi penggunanya. Semua penyedia jasa informasi saling berlomba dengan respon yang beragam guna memberikan pelayanan yang terbaik dengan harapan penggunanya untuk tetap setia memanfaatkan jasanya. 
Salah satu perpustakaan $\mathrm{X}$ terus mengembangkan strateginya. Perpustakaan $\mathrm{X}$ telah menerapkan konsep Manajemen Pengetahuan (KnowM). Konsep KM dimasukkan ke dalam strategi pelayanan sehingga semua pustakawannya dapat mendukung perpustakaan $\mathrm{X}$ untuk mendukung visi, misi, dan tujuannya. Sebagai perpustakaan yang relatif besar, Perpustakaan X memiliki relatif banyak karyawan yang tersebar diberbagai divisi. Organisasi besar memiliki praktek komunikasi internal yang relatif lemah dari organisasi yang lebih kecil karena spesialisasi pekerjaan dan pemisahan fungsional telah mengurangi akses ke informasi tentang layanan yang disediakan. Dengan kata lain, organisasi kecil memiliki jaminan lebih besar dari praktek komunikasi internal yang efektif.

Distribusi informasi tentang pengembangan perpustakaan tidak dapat bergantung hanya dari lisan ke lisan saja. Pustakawan perlu tahu apa yang terjadi di perpustakaan sebelum pihak luar tahu terlebih dahulu. Oleh karena itu, perpustakaan X memiliki unit yang disebut Pusat Belajar. Pusat belajar tersebut digunakan semua pustakawan, baik yang masih baru atau yang sudah lama, belajar dan menambah pengetahuan tentang perkembangan perpustakaan $\mathrm{X}$ dan informasi lainnya yang dibutuhkan. Dalam jangka waktu 1 tahun, Pusat belajar, tersebut dapat diorganisir dengan baik. Pusat Belajar tersebut merupakan cikal bakal berbagi pengetahuan dan didorong untuk dilakukan di setiap devisi. Program CoP dijalankan pada setiap devisi.

Pusat pembelajaran memantau berbagai topik yang dibahas pada CoP untuk memastikan bahwa CoP beroperasi sebagaimana mestinya. CoP menjadi lebih penting untuk fungsi organisasi yang menghargai pengetahuan sebagai aset utama. Pengetahuan diciptakan dari setiap tugas yang dilakukan oleh setiap pustakawan di perpustakaan, hal itu dapat didistribusikan, direkam, diulas dan diteruskan kepada semua anggota komunitas.

Dalam perkembangannya CoP di Perpustakaan X memenuhi sejumlah fungsi dan menjadi hal yang positif dari penciptaan, pengumpulan, dan penyebaran pengetahuan dalam suatu organisasi. CoP membantu dalam membangun beberapa hal positif : belajar mandiri, menciptakan inovasi dalam pekerjaan, menciptakan lingkungan yang bersedia untuk belajar, membangun hubungan yang kuat dalam organisasi serta memperkuat kepemimpinan.

CoP adalah cara untuk bertukar dan menginterpretasikan informasi. Karena pustakawan di dalam satu unit memiliki pemahaman bersama, mereka tahu apa yang relevan dikomunikasikan dan bagaimana untuk menyajikan informasi dengan cara yang bermanfaat. Akibatnya, sebuah CoP yang tersebar dalam suatu organisasi merupakan saluran yang ideal untuk memindahkan informasi, seperti praktik terbaik (best practitioners), tips, atau umpan balik dalam lintas-organisasi

CoP dapat mempertahankan pengetahuan dengan cara yang "hidup", bukan sebagai database atau secara manual. CoP mempertahankan aspek pengetahuan tersirat yang sistem formal tidak bisa "menangkap". Oleh karena itu, CoP ini ideal untuk memulai suatu hal yang baru. Para anggota CoP berdiskusi ide-ide baru, berkolaborasi pada isu-isu, dan menjaga perkembangan di dalam dan di luar organisasi. Dengan demikian, anggota CoP dapat membangun inovasi dalam pekerjaan mereka dan secara 
tidak langsung memotivasi mereka untuk bekerja lebih baik. Hal ini dapat membantu organisasi untuk memiliki hubungan yang kuat dengan pustakawannya. CoP membantu pustakawan untuk mengasah rasa percaya diri dalam anggota-anggota yang melakukan pembejaran. Hal ini terjadi karena dalam proses belajar-mengajar perasaan menjadi diperlukan dan kepercayaan berkembang. Selain itu, juga akan menumbuhkan rasa kepemimpinan itu sendiri. Keyakinan dan kepemimpinan yang memimpin para anggota dalam pelaksanaan pengetahuan dalam organisasi.

\section{Simpulan}

Berbagi pengetahuan pada Community of Practitioner dalam suatu lembaga tak terkecuali perpustakaan sangat dibutuhkan untuk membentuk individu-individu pembelajar antar sesama praktisinya. Community of Practitioner dibangun atas kesadaran tiap-tiap individu yang mempunyai kesamaan domain dan mempunyai i'tikad untuk terus mengembangkan pengetahuannya terkait suatu pekerjaan yang ditekuninya, walaupun ada juga yang memang diprakasai oleh manajemen. Konsep Community of Practitioner (CoP) mengacu pada proses pembelajaran sosial yang terjadi ketika orangorang yang mempunyai kepentingan yang sama dalam beberapa hal atau masalah berkolaborasi untuk berbagi ide, mencari solusi, dan membuat inovasi. Dengan pemenuhan fungsi dalam penciptaan, pengumpulan, dan penyebaran pengetahuan dalam suatu organisasi dan adanya contoh-contoh dari beberapa organisasi (perusahaan) kelas dunia, mengindikasikan bahwa CoP merupakan salah satu cara yang efektif dalam berbagi pengetahuan yang pada akhirnya akan meningkatkan kinerja organisasi. Aktifitas CoP penting untuk dikembangkan dalam dunia perpustakaan dalam mengembangkan keahlian para pustakawannya, sebab dengan adanya akfiritas CoP di perpustakaan dapat dipastikan akan mampu menjawab semua persoalan-persoalan yang ada diperpustakaan sebagaimana yang terjadi pada perusahaan-perusahan yang ada di dunia, terutuma dalam menghadapi perkembangan informasi berserta medianya yang kian semakin cepat mengalami perubahan.

\section{Daftar Pustaka}

Akib, Haedar dan Frans Gana. 2008. Kreatifitas dan Inovasi : Tujuan Menapaki jalan yang dilalui Community of Practitioner. Jurnal Bisnis dan Usahawan, Volume 6. Nomor 2. Januari

Ardi Reza Pradana: Knowledge Sharing Pada Community Of Practitioners di PT.Pembangkit Jawa Bali, Unit Pembangkit Gresik Departemen Informasi dan Perpustakaan - FISIP Universitas Airlangga. http://journal.unair.ac.id/download-fullpapers-Jurnal\%20Adi\%20reza.pdf

Tim Knowledge Management PT. PLN Persero No. 317.K/DIR/2009: Buku Panduan Pelaksanaan Community of Practitioner

Wenger, Etienne and Beverly - Trayner, 2015 Communities of practitioner A brief introduction - V April 
Veronica; Angellia Debora Suryawan. Community of Practitioner as one of the competitive advantage Of organization. International Journal of Communication \& Information Technology (CommIT) Vol. 6 No. 2 October 2012, pp. 85-89.

Wenger, Etienne C dan William M, Snyder. 2000. Communities of Practitioner: The Organizational Frontier. Harvard Business Review, Januari-Pebruari

Wenger, Etienne 2006 Communities of Practitioner A brief introduction, June,

Zed, Mestika 2003. Metode Penelitian Kepustakaan. Jakarta : Yayasan Obor Indonesia

Zulaiha, Siti 2008 Communities of Practitioner sebagai Sarana Efektif Berbagi Pengetahuan dalam suatu Organisasi. e-Indonesia Initiative 2008 (eII2008) Konferensi dan Temu Nasional Teknologi Informasi dan Komunikasi untuk Indonesia 21-23 Mei, Jakarta 